からやろうとする方々への一助となればさいわいである と考える。

\section{3. 当院におけるX線シネ撮影の現状について} 市立迪川病院 ○熊井 稔 心蔵カテーテル検査におけるシネアンジオは，心藏の 形態および動態を観察するのに有効な方法である。

循環器疾患の堌加に伴い, 当院でも昨年一年間のシネ アンジオは, CAG 141例，LVG 他77例の件数をかぞえ， まだ増加の傾向にある.そこで今回，一地方病院での心 臓カテーテル検査の現状について述べる。

内容としては，装置に関する事，フィルム処理に関す る事，被曝に関する事等について文献考察を含め意見を 述べ，具体的な臨床例を提示し，シネアンシオ画像にお ける問題点等について考察を加える.

\section{4. 心・大血管疾患の診断における CT の特徵と有用性 北海道大学附属病院放射線部门过宏}

心，大血管系疾患の骖断に执いて，CT 検查法は非常 に有用であり，この検查法は著しい早さで拡がりつつあ る。当院に㧊いても，昭和 56 年 5 月はシーメンス社製 Somatom 2 が設置され，この分野での研究および臨床 への応用がなされてきた。

今回 plain CT, contrast CT, dynamic scan, 心電図 同期 $\operatorname{scan}$ の循環器疾患への特徽, 特性を種々検討した.

さらに dynamic scan の動脈瘤の検出, A-C バイパス 開存性の評価，シャントの有無の判定への利用法と心電 図同期 scan の検査法，心機能を含めた評価法など種々 検討した。

以上より，心，大血管系疾患に非常に有效であったも の, 現在研究段階でありとれから使用されるもの, その 他問題点，乙れらを各々考察を加え報告する.

\section{座長集約}

新健治（金谷病院）

予定発言者 金谷病院副院長，木住野陆

総合画像診断は臨床診断の過程で，種々の医用画像を， その特質にしたがって取捨選択し，診断過程の最適化を 行なうものであり，色々の“Decision Tree”が提案され ている. この総合画像診断の立場の中で，技術面での検 討は第 8 回放射線シンポジウムで「総合医用画像につい て」として取り上げられている.

今回のシンポジウムでは，各種の医用画像を医師に提 出するに当って，他の医等情報を知る事によって，より 良い結果を提出できるようになった事例を整理考察する 事により，新しく技術の深度化が計れるのではないかと 考えて企画した.
四人の演者には日頃担当している. US, RI，CT， CINE を中此に，それぞれの検查法の特徴を述べていた だき，検査を行なう時，あるいは data 整理する際に， それまでの患者情報が有用であった事柄から，考えられ た事について述べていただきたいと思う。

それぞれ特色ある技術が互いの長所を発揮して，より 発展したものになる。つまり良い共鸣（ハーモニィ）が 生れる事を期待して坐長の提起とする.

また, シンポジウム打合せ会の話し合いの中から, 臨 床側の考え方を聞きたいと，意志がまとまったので，金 谷病院副院長・木住野陆先生に “医㽞床医が画像技術に期 待する”靴意見を述べていただいた。

\section{一般研究発表}

撮 影一 1

座長 菊池 務 君 (北海道大学医学部附属病院)

1. 試作補僙型蛍光紙による胸部間接 $(100 \mathrm{~m} / \mathrm{m}$ ミラー カメラ）撮影について

岩見沢労災病院

○冨樫 健・武部紀司・葉正克

羽兼慶一・杉木 健・阿波加正弘

近年，国内における早期がん刘策のなかで，肺がん検 診の重要性が急速に高まっている。

従来気管および気管分岐部, 縦隔部の示現は困難とさ れていた. 本補償型监光紙（希土類：グラディションタ イプ）によれば相当程度の示現可能である.

展示を兼ねて発表するが，将来肘がん検揨への 1 ステ ップとして何らかの参考になれば幸䓕である。

\section{Bi-plane cine angio 装置の使用経験} 北海道立小児総合保健センター放射線科

○斉藤哲夫・宮沢憲夫 藤沢忠之・柏木茂喜

近年, 循環器系検查に bi-plane cine angio 装置を使 用する施設が増えつつある，われわれも，昭和57年10月 よりフィリップス社製 bi-plane cine 装置により循環器 系検查を施行している．われわれの cine system は，1 タンクによる擬似 bi-plane 方式で，I・I は検査部位を常 にアイソセンターにポザショニングできる特長をもつ.

Bi-plane cine angio の画質を向上させる一つの要因 は，1駒当りの入射線量の決定と，カブリを防止する branking 時間の決定である。これらについて若干の実 験と検討を試みたので報告する。

\section{3. 立体拡大撮影 $\mathrm{X}$ 線管球の使用経験}

日鋼記念病院放射線科

○以口政志・伊藤英樹・小島 洋 